\title{
A new species of the rare endoparasitic copepod Entobius (Copepoda: Entobiidae) from Mexico with a key to the species of the genus
}

\author{
Eduardo Suárez-Morales and Luis F. Carrera-Parra
}

\author{
El Colegio de la Frontera Sur (ECOSUR), Unidad Chetumal, Av. Centenario Km. 5.5, Chetumal, Quintana Roo 77014, Mexico
}

\begin{abstract}
In a study of the benthic polychaete fauna of the southern Gulf of Mexico and the Caribbean Sea, several specimens of the terebellid polychaete Scionides reticulata (Ehlers) were found to host endoparasitic copepods that represent an undescribed species of the rare cyclopoid genus Entobius Dogiel, 1948. The new species, E. scionides sp. n., can be distinguished from its congeners by a combination of characters including a genital region without constrictions, three-segmented antennules, a reduced antenna with a blunt terminal process, reduced ornamentation of endopods of legs $1-4$ and its relatively small size (2.3-2.7 mm). It is the smallest species of the genus. Comments on immature females are also provided, but males of this species remain unknown. It has a high prevalence (53\%) in populations of the terebellid S. reticulata in the southern Gulf of Mexico, but it is absent from the Caribbean. This is the first occurrence of this copepod genus in the Americas. The finding of the new species of Entobius in S. reticulata confirms the strict specificity of most members of the genus and expands the host range of this copepod genus. A key for the identification of the species of Entobius is provided.
\end{abstract}

Keywords: symbiotic copepods, parasitic crustaceans, invertebrate taxonomy, benthic polychaetes, endoparasites

The copepod family Entobiidae Ho, 1984 was established to include endoparasitic forms with laterally inserted biramous unsegmented legs $1-4$, fifth pedigerous somite partially fused with prosome to form a long trunk and genital complex fused with the anal somite to form a genitoabdominal tail unit. Entobiids have reduced antennules and antennae, uniramous mandibles, the maxillae are absent, the maxilliped is a robust, prehensile appendage, and leg 5 is reduced to a single seta (Gotto 1966, Ho 1984, Boxshall and Halsey 2004). These are endoparasitic forms that have been recorded exclusively from the gut of a few species of terebellid polychaetes (Gotto 1966, 2004, Boxshall and Halsey 2004). The family is monotypic, being represented by the genus Entobius Dogiel, 1908 that includes three species only, namely $E$. loimiae Dogiel, 1908; E. euelpis Barnard, 1948; and E. hamondi Gotto, 1966. These species have been recorded from different geographic areas: British waters, off Plymouth (E. hamondi), Red Sea (E. loimiae) and South Africa (E. euelpis) (Barnard 1948, Gotto 1966, 2004).

Terebellid polychaetes identified as Scionides reticulata (Ehlers, 1887) were collected at different times from benthic habitats of the southern Gulf of Mexico and from the western coast of the Caribbean Sea. Some of these specimens were examined for symbionts and found to host endoparasitic copepods, which were sorted and studied taxonomically. These specimens represent an un- described species of Entobius, which is described here based on females and compared with known congeners. Also included is a key for the identification of the known species of Entobius.

\section{MATERIALS AND METHODS}

Polychaetes were obtained by gradual fragmentation of coral rocks using a hammer and chisel. They were fixed in a $10 \%$ formalin solution after osmotic shock relaxation with freshwater. Specimens were then transferred to $70 \%$ ethanol. Examination of the body of some of these polychaetes allowed us to detect several copepods lodged in the gut. Copepods were extracted from the hosts and transferred to $70 \%$ ethanol with a few drops of glycerine for long-term preservation. The specimens were examined using a compound microscope; most specimens were left undissected. Two female specimens were prepared for SEM (Scanning Electron Microscopy) following standard methods. Observations were performed using a JEOL LV-5900 microscope at facilities of the Universidad Autónoma de México. Other specimens were mounted in semi-permanent slides with glycerine sealed with Entellan ${ }^{\circledR}$, a commercial, fast drying mounting medium and sealant. Scaled drawings were prepared with the aid of a camera lucida.

Type specimens were deposited in the National Museum of Natural History, Smithsonian Institution, Washington, D.C. (USNM), in the Collection of Zooplankton of El Colegio de la Frontera Sur at Chetumal, Mexico (ECO-CHZ), and in the Institute of Parasitology, Academy of Sciences of the Czech Republic, Czech Republic (IPCAS). 


\section{RESULTS}

Order Cyclopoida Burmeister, 1834

Family Entobiidae Ho, 1984

Genus Entobius Dogiel, 1908

\section{Entobius scionides sp. $\mathrm{n}$.}

Figs. 1-5

Description of female: Average total length of body measured from anterior end of cephalothorax to posterior margin of anal somite: $2.31 \pm 0.16 \mathrm{~mm}(\mathrm{n}=4$; length of holotype $2.27 \mathrm{~mm}$ ). Body (Figs. 1A, 2A) robust, fleshy, caterpillar-like, most of cuticular surface covered with patches of short, hair-like elements. Cephalic region well defined, representing about $15 \%$ of total body length; cephalosome bearing mouthparts and simple, elongate rostrum tapering distally (Fig. 3E). Dorsal surface of ce- phalic region partially covered by wide U-shaped patch of pilose elements (Fig. 3A-C). Dorsal frontal margin with posteriorly directed curved process juxtaposed to cuticular surface, processes widely separated from each other (Fig. 3B). Cephalosome followed by four pedigerous somites separated by shallow intersomite divisions. Fifth pedigerous somite separated from genital somite by poorly defined intersomite suture, marked by weak constriction. Genital and fifth pedigerous somites together representing about $34 \%$ of total body length (Figs. 1A, 2A,B); this large somite with posterolateral lobes reaching about mid-length of subtriangular anal somite (Fig. 2B). Genital apertures paired, egg sac slightly longer than body. Anal somite carrying cylindrical caudal rami. Caudal rami (Figs. 1G, 4D) cylindrical, moderately divergent, with pilose surface. Rami about as long as anal somite,
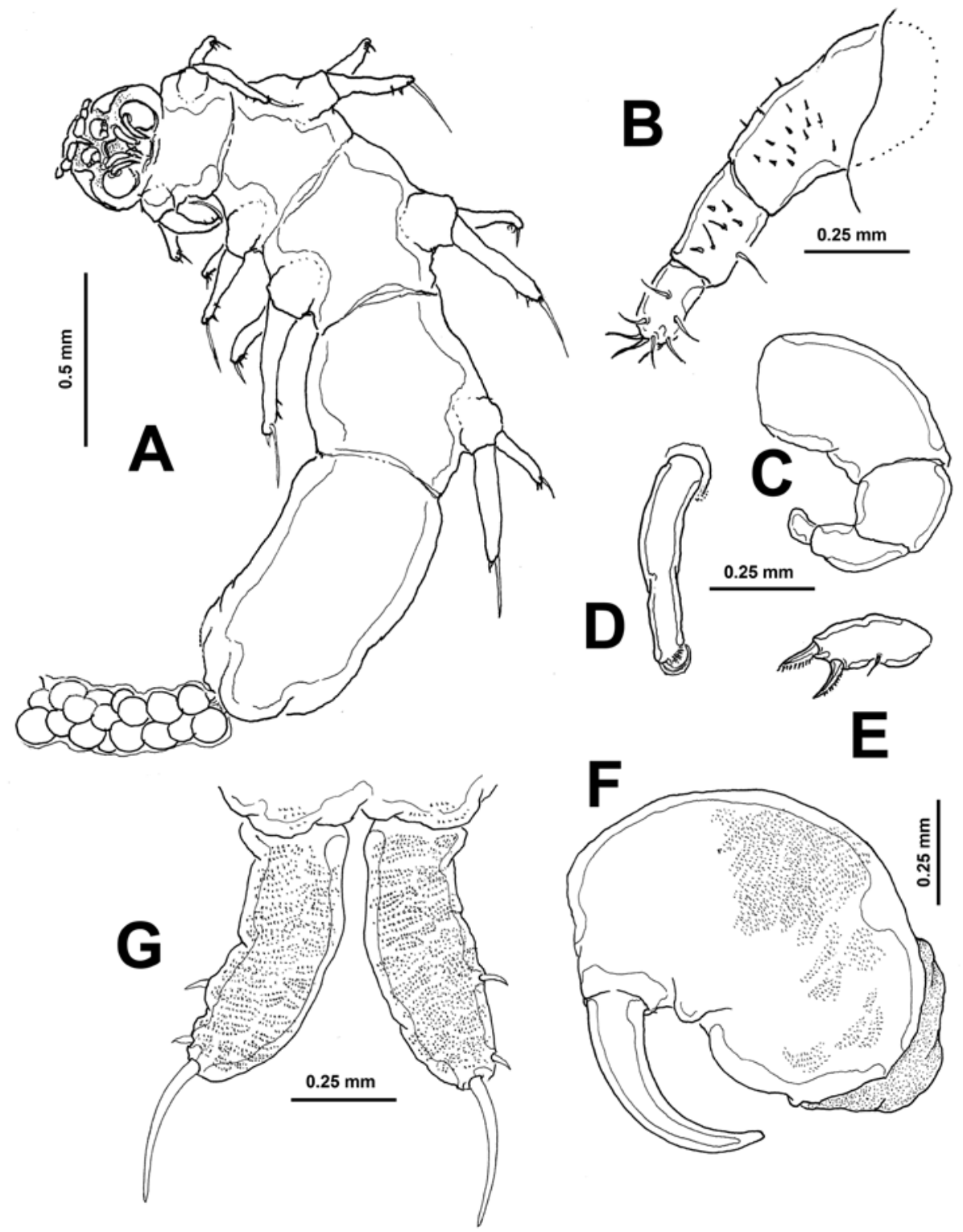

Fig. 1. Entobius scionides sp. n. from Scionides reticulata, Gulf of Mexico; holotype - ovigerous female. A - habitus, ventral view, egg sacs cut short; B - antennule, dorsal view; C - antenna; D - mandible; E - maxillule; F - maxilliped; G - caudal rami. 


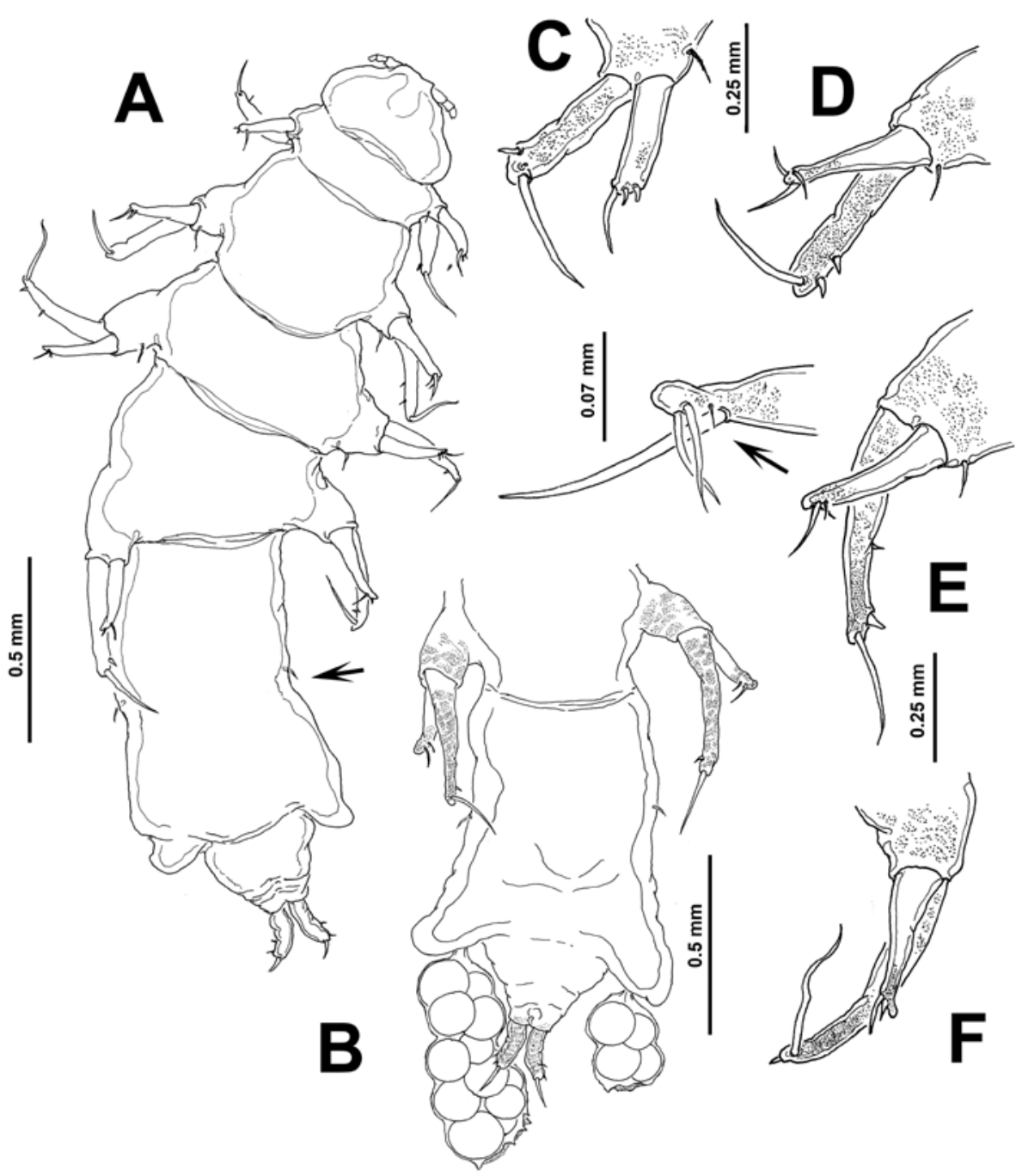

Fig. 2. Entobius scionides sp. n. from the Gulf of Mexico. A - habitus, dorsal view (paratype specimen, fifth leg arrowed); $\mathbf{B}$ - fourth pedigerous somite and genital area, ventral view (holotype), egg sacs cut short; $\mathbf{C}-\operatorname{leg} 1 ; \mathbf{D}-\operatorname{leg} 2 ; \mathbf{E}-\operatorname{leg} 3$ and detail of exopod of leg 3 (arrow); $\mathbf{F}-\operatorname{leg} 4$.

armed with three or four setae, longest one distal, two or three shorter ones (about 1/6 length of terminal seta) on outer lateral margin.

Antennule (Fig. 1B) short, robust, three-segmented, first segment longest. Second segment shorter than first one, both with field of pilose elements (Fig. 3B). Armature reduced, represented by small spiniform setal elements scattered on surface of segments. Number of elements/segment: $15,8,7$.

Antenna (Fig. 1C) three-segmented, robust, uniramous. First segment globose, second segment subrectangular, shorter. Distal segment short, with small distal lobular process instead of usual spine-like element.

Labrum subtriangular, with rugose frontal edge. Mandible (Fig. 1D) slender, cylindrical, unsegmented, with distal curved process and subdistal row of short spinules, palp absent.
Maxillule (Fig. 1E) reduced, concealed by elongate mandible, represented by single lobe bearing two relatively strong distal setae with lightly spinulate outer margin and short inner proximal seta. Maxilla absent.

Maxilliped (Fig. 1F) well-developed, three-segmented. Reduced syncoxa at base of appendage, followed by robust, globose basipod with field of minute spinules. Terminal claw forming strong curved hook.

Legs 1-4 (Fig. 2C-F) fleshy, increasing in size posteriorly, inserted laterally on body. Intercoxal sclerites absent. Basipodites short, with outer basipodal seta on legs 1-3. Exopods of legs 1-4 shorter than endopods, both rami unsegmented, tapering distally. Rami with distal or subdistal armature only, inner margin unarmed. Surface of basipods, endopods and exopods of legs 1-4 with patches of small spinules. Exopods with patches only on distal part, extensive on endopods (Fig. 4A-C). Two distal elements on leg 1 peg-like, not setiform or spiniform. 

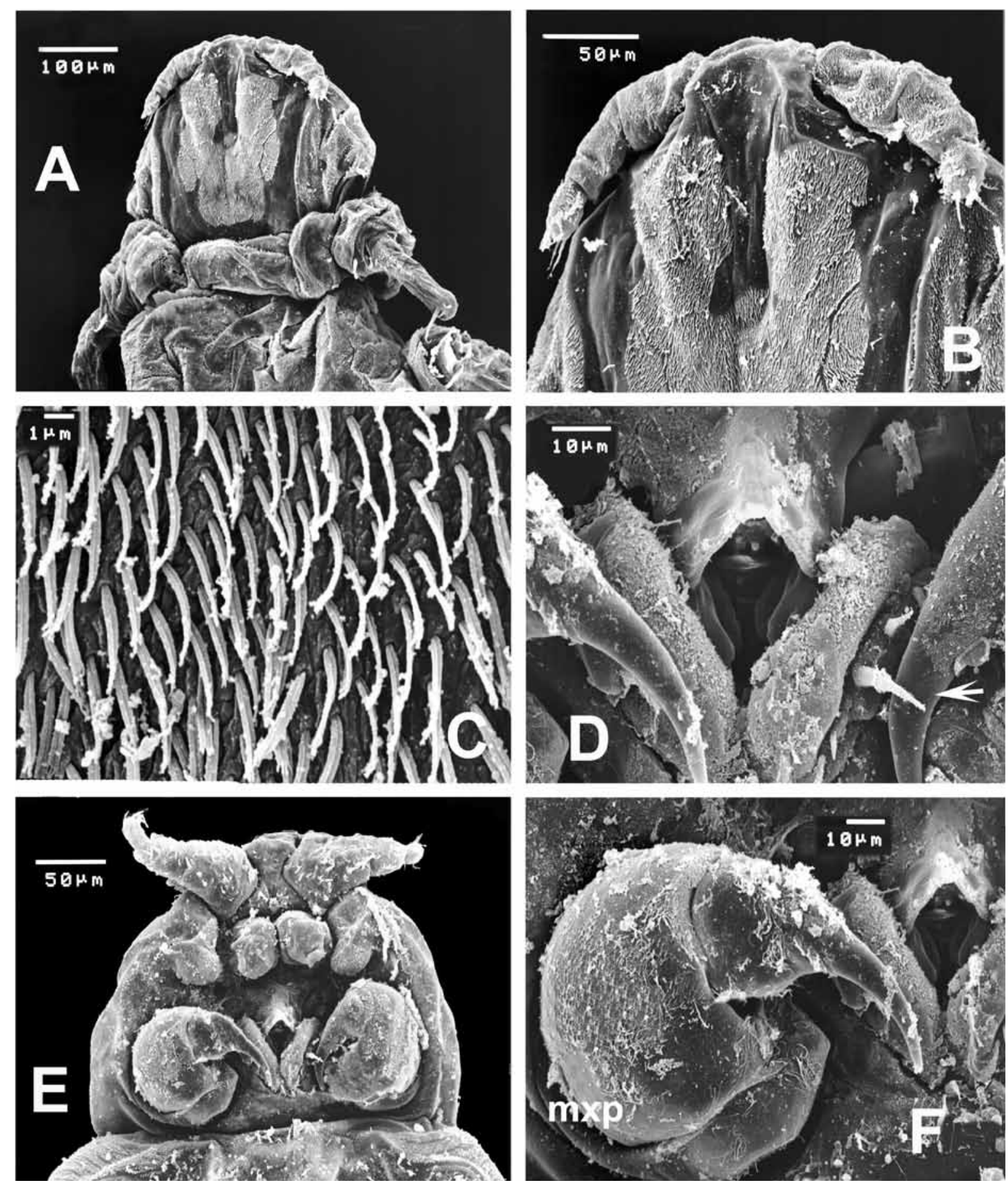

Fig. 3. Entobius scionides sp. n. from the Gulf of Mexico; scanning electron micrographs (SEM). Adult female: $\mathbf{A}$ - cephalic region, dorsal view; B - same, showing U-shaped patch on dorsal surface; $\mathbf{C}$ - detail of pilose ornamentation of cephalic surface. Immature female: D - oral area, ventral view, maxillule arrowed; $\mathbf{E}$ - cephalic region, ventral view; $\mathbf{F}$ - maxilliped (mxp), ventral view.

Spine and setal formula of legs $1-4$ as follows:

\begin{tabular}{lccc}
\hline & basis & exopod & endopod \\
\hline leg 1 & $1-0$ & $0-3$ & $0-2$ \\
$\operatorname{leg} 2$ & $1-0$ & $0-3$ & $0-3$ \\
leg 3 & $1-0$ & $0-4$ & $0-3$ \\
leg 4 & $0-0$ & $0-2$ & $0-2$ \\
\hline
\end{tabular}

Fifth leg reduced, represented by short seta inserted on distal part of fifth pedigerous somite (Fig. 2A, arrowed). Leg 6 represented by genital opercula (not shown).

Immature females: Smaller than adult females, average length $1.29 \mathrm{~mm} \pm 0.16 \mathrm{~mm}(\mathrm{n}=10)$. Body shape and proportions (Fig. 5A,B) as in adults. Earlier female copepodite $(0.6 \mathrm{~mm})$ also observed (Fig. $5 \mathrm{C})$. Cephalic 

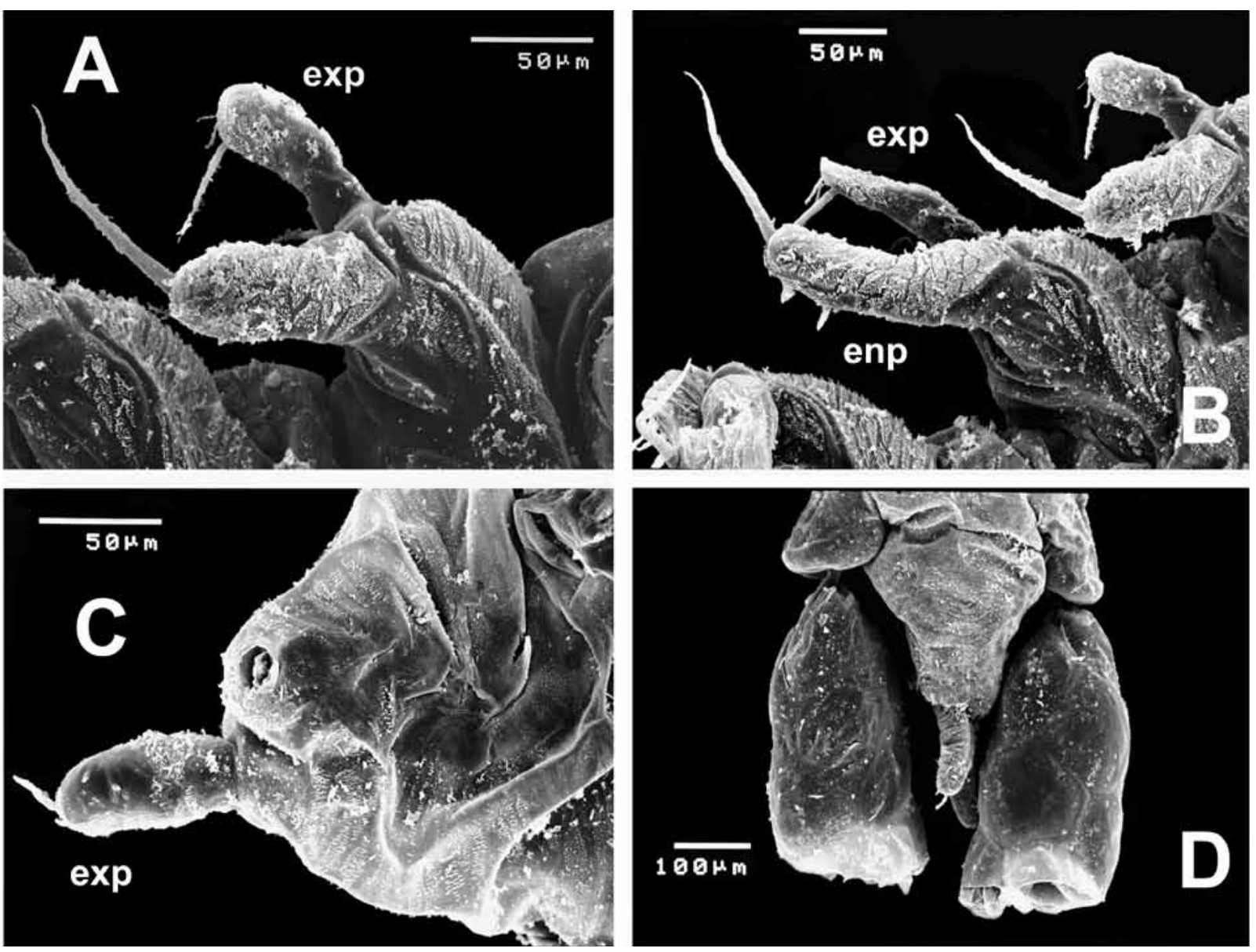

Fig. 4. Entobius scionides sp. n., from the Gulf of Mexico; SEM. A - leg 1 showing cuticular ornamentation; B - leg 2; C - leg 4, endopodal ramus missing; D - posterior part of genital area showing lateral processes and egg sacs (broken), ventral view. Abbreviations: end - endopod, exp - exopod.

appendages and mouthparts, including antennules, antennae, labrum, mandibles and maxillipeds (Fig. 3D-F) as in adults. Maxillule as in adult female except for naked distal setae (arrowed in Fig. 3D) instead of spinulate elements. Legs 1-4 as in adult except for one setal element less on endopod of leg 1, one less on leg 3 (Fig. 5A,B). Fifth legs represented by single seta. Tail region including genital somite and free somite distinctly segmented (Fig. 5A,B). Caudal rami as in adult.

Male: Unknown, although the segmentation of the small specimen illustrated in Fig. 5C suggests that this could be a male or an immature male.

Type host: The benthic terebellid Scionides reticulata (Ehlers, 1887) (Polychaeta, Terebellida).

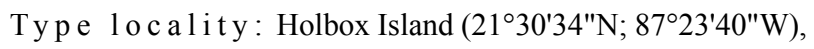
Quintana Roo, Mexico.

Distribution: Gulf of Mexico (from Campeche to Quintana Roo, Mexico).

Site of infection: Copepods were found anchored to the inner walls of the gut of polychaete specimens of Scionides reticulata, mainly between chaetigers 17-30 (Fig. 6).

Etymology: The species is named by apposition as the genus of the terebellid polychaete from which it was obtained.
Material deposited: Holotype: adult ovigerous female collected by L.F. Carrera-Parra (ECOSUR) from Holbox Island, northern coast of the Yucatan Peninsula, southern Gulf of Mexico, Northwestern Tropical Atlantic Ocean, depth of $1 \mathrm{~m}, 4$ May 2000, undissected specimen, slide sealed with Entellan ${ }^{\circledR}$ (USNM-1186168). Paratypes: adult female from same host and locality, specimen undissected, slide sealed with Entellan ${ }^{\circledR}$ (USNM-1186169). Two immature females from same host, date of collection, and locality, undissected, ethanol-preserved, vial (USNM-1186170). One adult female, specimen broken in two parts, slides sealed with Entellan ${ }^{\circ}$ (ECO-CHZ-07571); one immature female from same host, date and locality, ethanol-preserved, undissected, vials (ECO-CHZ-07572). One immature female from same host, date and locality, undissected, slide sealed with Entellan ${ }^{\circledR}$, deposited in the Institute of Parasitology, Academy of Sciences of the Czech Republic (Coll. No. Cr-13).

Host-parasite data: From the same sample from which type specimens were collected, a total of 30 individuals of $S$. reticulata were examined. Sixteen polychaete specimens $(53 \%)$ were infected, 11 of them hosting only one copepod and the remaining five harboured two copepods in their body. This high prevalence decreased to $34 \%$ when other samples of the same polychaete spe- 


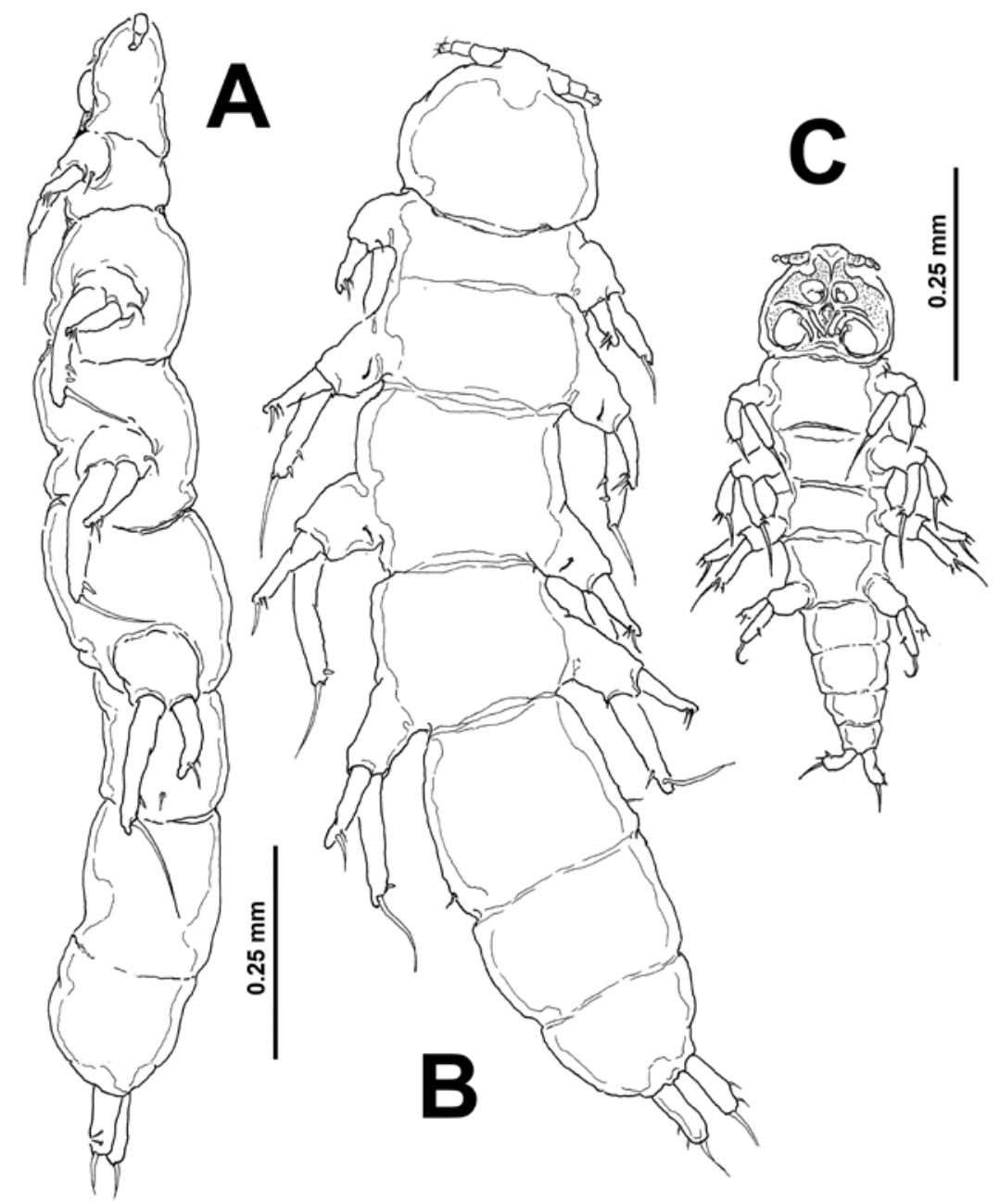

Fig. 5. Entobius scionides sp. n. from the Gulf of Mexico, immature female. A - habitus, lateral view; B - same, dorsal view; C - early copepodite, ventral view.

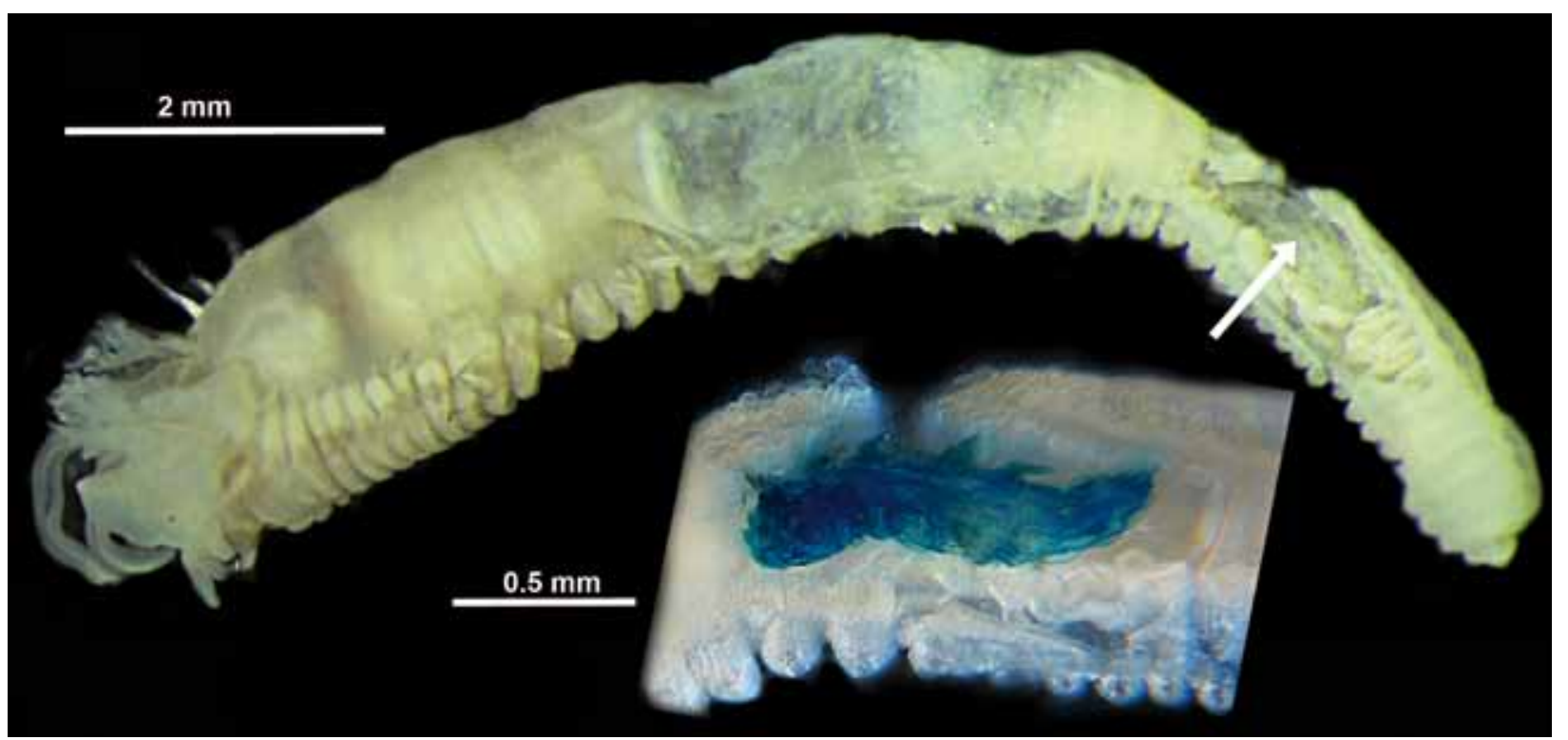

Fig. 6. Scionides reticulata and immature female of Entobius scionides sp. n. from the Gulf of Mexico; arrow indicates position of parasite inside the host gut. Copepod stained with methylene blue. 
cies collected in the Gulf of Mexico were considered for the estimation of this parameter. Actual infection rates may be higher in the region because many of the polychaetes hosts examined were incomplete. In addition, it is noteworthy to mention that none of the specimens of $S$. reticulata collected in the Caribbean Sea sites $(n=35)$ was infected. The smallest infected terebellid individual had only 38 chaetigers with a thoracic width of $1.0 \mathrm{~mm}$, whereas the largest has 71 chaetigers and was $2.3 \mathrm{~mm}$ wide. We did not find any relationship between host size and the presence of copepods.

The new species seems to be specific to $S$. reticulata because the copepod was absent in other species of terebellids, such as Streblosoma hartmanae Kritzler and Lanicola carus (Young et Kritzler), both present in the same samples containing the infected specimens of $S$. reticulata.

Remarks: The specimens examined were identified as members of the genus Entobius for their possession of the diagnostic characters of the monotypic family Entobiidae (Gotto 1966, Ho 1984, Boxshall and Halsey 2004). In addition, we considered the fact that they were collected from the inner gut of a terebellid polychaete, as all other known members of this genus (Gotto 1966, 2004). The new species differs from its congeners in the following characters: The antennule is three-segmented, thus differing from those of E. hamondi and E. loimiae, both with four-segmented antennules. Entobius scionides lacks a constriction between the fifth pedigerous somite and the genital somite; this constriction is present in E. loimiae and E. euelpis. The antennae of the three known species of the genus and the Entobius sp. reported by Boxshall and Halsey (2004) have a terminal segment armed with a relatively long spiniform element (Dogiel 1908, Barnard 1948, Gotto 1966, Boxshall and Halsey 2004). This element is represented in the new species by a knob-like process, which is a unique character. In addition, in other species of Entobius the endopods of legs 1-4 are armed with a row of setal elements along the inner margin; in contrast, the inner margin of legs $1-4$ endopods is naked in $E$. scionides. The new species is also the smallest species of the genus, the average size of adult females (less than $2.5 \mathrm{~mm}$ ) being smaller than that of the other species of Entobius: E. loimiae (3.5-4.0 mm), E. hamondi (4.2$4.4 \mathrm{~mm})$ and E. euelpis $(8.0 \mathrm{~mm})$ (Boxshall and Halsey 2004).

\section{DISCUSSION}

With the addition of the new species, Entobius scionides, there are currently four nominal species in the genus. Adult females of each of the known species of the Entobiidae have been recorded only as endoparasites of a particular terebellid worm species: E. loimiae is known only from Loimia medusa (Savigny in Lamarck), E. hamondi from Polycirrus caliendrum Claparède and E. euelpis from an unknown terebellid (Dogiel 1908, Barnard 1948, Gotto 1966). An undescribed species reported by Boxshall and Halsey (2004) was found in two species of Polycirrus, $P$. plumosus (Wollebaeck) and $P$. cf. medusa.

The new species, E. scionides, is recorded only from Scionides reticulata, even though other terebellids were found in the same samples from the Gulf of Mexico. This report expands the host range of this copepod to another terebellid genus and represents the first record of the family in the Americas. Its terebellid host, S. reticulata, is widely distributed in the region; however, it is noteworthy that the copepod was found only in terebellids collected in the Gulf of Mexico, being absent in specimens from the same host in the Caribbean Sea.

The position of the specimens of E. scionides within the gut of the polychaete host coincides with the observations made by the other authors reporting entobiid copepods as endoparasites (Gotto 1996, 2004, Boxshall and Halsey 2004). Adult and immature female individuals of the new species were most probably living as motile internal parasites (Boxshall and Halsey 2004).

Ho et al. (2006) suggested a close phylogenetic position of the Entobiidae and the Umazuracolidae because both groups have a bilobate maxillule, a one-segmented leg 1 endopod and a leg 5 reduced to a single seta. This couple (Entobiidae + Umazuracolidae) was in turn deemed to be related to the Nereicolidae, a family containing polychaete parasites. The authors proposed that this group of polychaete-parasitizing forms is probably related to ancestors of the Umazuracolidae, parasites of teleosts.

However, Huys et al. (2011) refuted this assumption, indicating that the Umazuracolidae is not a valid taxon; they also questioned the presumed relation of this group with the Entobiidae. Thus, relations of the Entobiidae remain unclear because of the lack of segmentation of legs 1-4 (Boxshall and Halsey 2004) and the invasion of polychaetes as hosts is probably an independent strategy that has been displayed by other groups among the Copepoda, although few are true endoparasitic forms like entobiids.

In order to facilitate species identification, a key to species of Entobius is provided:

\section{Key to the species of Entobius (Cyclopoida) \\ Females}

1A Antennule four-segmented 2

1B Antennule three-segmented 3

2A Body without constriction between genital somite and preceding (fifth pedigerous) somite; caudal rami relatively short, about half the length of anal somite Entobius hamondi Gotto, 1966

2B Body with constriction between genital somite and preceding (fifth pedigerous) somite; caudal rami 
about as long as anal somite

Entobius loimiae Dogiel, 1908

3A Distal segment of antenna with long terminal spine; inner margin of endopodal rami of legs 1-4 with row of setal elements additional to distal setation; large species $(8.0 \mathrm{~mm})$

Entobius euelpis Barnard, 1948

3B Distal segment of antenna with knob-like process; inner margin of endopodal rami of legs 1-4 naked except for distal armature; small species (less than $3 \mathrm{~mm}$ )

Entobius scionides sp. $\mathrm{n}$
Acknowledgements. The copepods were collected as part of an institutional project at ECOSUR-Chetumal to reveal the diversity of the benthic polychaetes of the Northwestern Tropical Atlantic. We thank Silvia Espinosa Matías (Laboratorio de Microscopía Electrónica de Barrido, Facultad de Ciencias, UNAM, Mexico) for helping us in obtaining SEM photomicrographs. Rosa María Hernández (ECOSUR, Mexico) deposited type specimens in the Collection of Zooplankton at ECOSUR Chetumal. We also thank Chad Walter and Paul Greenhall for depositing type specimens at the National Museum of Natural History, Smithsonian Institution, Washington, D.C.

\section{REFERENCES}

BARNARD K.H. 1948: New records and descriptions of new species of parasitic Copepoda from South Africa. Ann. Mag. Nat. Hist. 12: 242-254.

Boxshall G.A., Halsey S.H. 2004: An Introduction to Copepod Diversity. The Ray Society, London, 966 pp.

Dogiel V.A. 1908: Entobius loimiae n. g. n. sp., eine endoparasitische Copepode. Zool. Anz. 33: 561-567.

Gотто R.V. 1966: Entobius hamondi n. sp., a copepod associated with a terebellid worm. Crustaceana 11: 156-162.

Gotтo R.V. 2004: Commensal and parasitic copepods associated with marine invertebrates (2nd edition). Synopses of the British Fauna No. 46. Linnean Society of London and Estuarine and Coastal Sciences Association by Field Studies Council, Shrewsbury, UK, 352 pp.
Ho J.-S. 1984: New family of poecilostomatoid copepods (Spiophanicolidae) parasitic on polychaetes from southern California, with a phylogenetic analysis of nereicoliform families. J. Crust. Biol. 4: 134-146.

Ho J.-S., Ohtsuka S., Nakadachi N. 2006: A new family of poecilostomatoid copepods (Umazuracolidae) based on specimens parasitic on the black scraper (Thamnaconus modestus) in Japan. Zool. Sci. 23: 483-496.

Huys R., Fatih F., Ohtsuka S., Llewellyn-Hughes J. 2011: Evolution of the bomolochiform superfamily complex (Copepoda: Cyclopoida): new insights from ssrDNA and morphology, and origin of umazuracolids from polychaete-infesting ancestors rejected. Int. J. Parasitol. 42: 71-92. 